\title{
Effect of depot-medroxyprogesterone acetate injections on serum immunoglobulins and complements level cohort study
}

Wahda B. Al-Youzbaki

Department of Pharmacology, College of Medicine, University of Mosul

$\begin{array}{ll}\text { Received: } & \text { Accepted } \\ \text { rv.o.r..v } & \text { r.l1.r...v }\end{array}$

\begin{abstract}
Background: Depot medroxyprogesterone acetate (Depo-Provera) is a highly effective, nondaily hormonal contraceptive option that has been available in the worldwide for $\varepsilon \cdot$ years and provides a very high level of contraceptive efficacy. Benefits and risks of hormonal therapy are often under scrutiny, however, long-term clinical experience has established the safety of this long-acting contraceptive in that it does not increase the risk of cardiovascular events, breast cancer, other gynecologic malignancy, or postmenopausal fracture.
\end{abstract}

Aim: To evaluate the effect of depot medroxyprogesterone acetate injections on the serum immunoglobulin (IgG, $\operatorname{lgM}, \lg A)$, and complements (Cr,C $\{$ ).

Study design: Prospective cohort study.

Study period: $1^{\text {st }}$ January $r \cdots r$ to $r{ }^{\text {st }}$ March $r \cdots r$.

Subjects \& Methods: Thirty healthy married women, their age ranged between $r \cdot-r_{0}$ years, who were attending Al-Batool and Al-Khansa Family Planning Centers in Mosul/ Iraq and started (for the first time) to use depot medroxyprogesterone acetate (DMPA) injection. Each injection contains 10. mg medroxyprogesterone acetate. These women called DMPA users group, were compared to another thirty healthy married women who did not use any hormonal contraceptives and were drawn from the same population and matched for age, height and weight with the DMPA users group, and they were considered to be the non users group. Both groups were followed for one year, during which blood samples were obtained from both groups, before starting to use DMPA, after 7 months and then after $1 r$ months. The sera obtained from the blood samples were used for the estimation of the biochemical studied parameters using commercial kits.

Results: Serum IgG was significantly elevated after $1 r$ months $(p=\cdot . r \wedge)$ among DMPA users in comparison to non users but non significant increase according to the duration of use. While there was a non significant changes in the serum $\operatorname{lgM}, \lg A, C r$ and $C$ \& level after $r$ and $I r$ months in the DMPA users in comparison with non users and in relation to the duration of use. DMPA caused a non significant changes in the total serum protein and serum albumin levels.

Conclusion: The significant raise of serum levels of IgG may be indicative of improved humeral immunity in DMPA Iraqi users, a change that is potentially beneficial.

Keywords: immunoglobulin, complements, depot-medroxyprogesterone

الخلفية: حقن مخزن ميدروكسي بروجيستيرون أسيتيد هي من موانع الحمل الهرمونية عالية الكفاءة والتي لاتعطى يوميا

ومتوفره في العالم منذ أربعين عاما وتعطي منع حمل عالي الكفاءة. فوائد و مخاطر العلاج بالهرمونات عادة تحت

الفحص و التدقيق و مع هذا فان التجارب السريرية أثنتت أن موانع الحمل طويلة المفعول مأمونة من ناحية أنها لاتزيد من

خطورة أمر اض القلب الثريانية، سرطان الثدي و السرطانات النسائية الأخرى ولا الكسور بعد سن اليأس . 


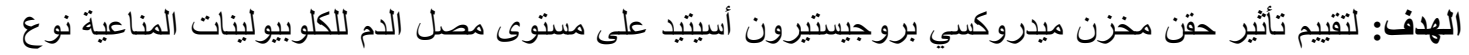
( IgA)A , (IgM)M, (IgG)G بروجيستيرون أسيتيد.

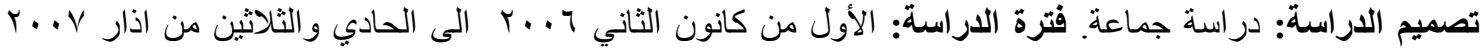

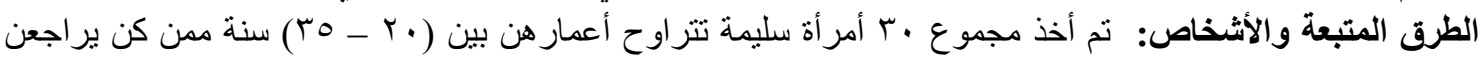

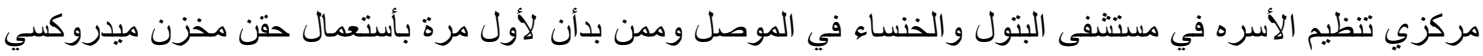

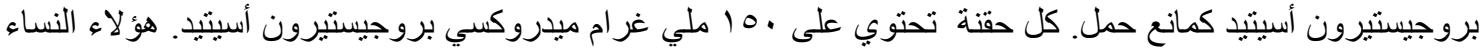

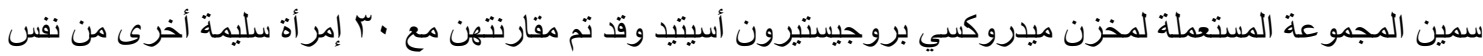

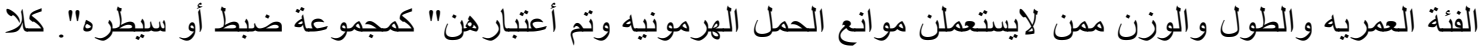

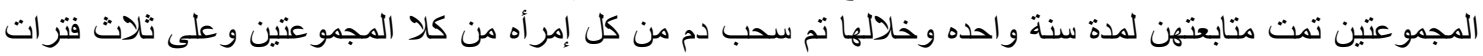

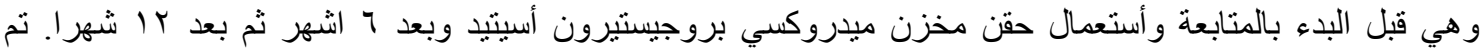

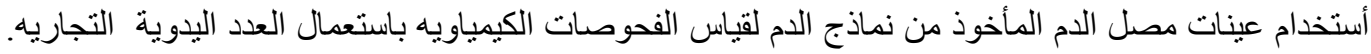

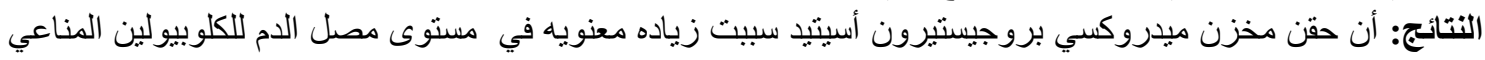

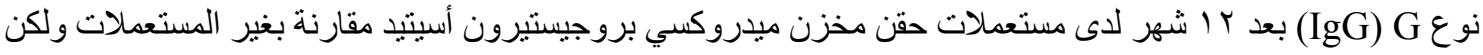

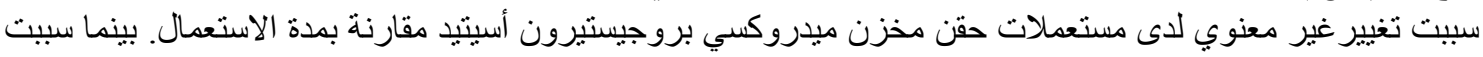

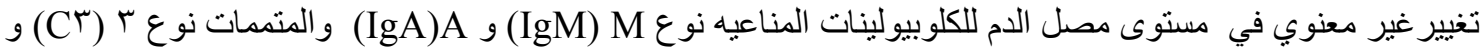

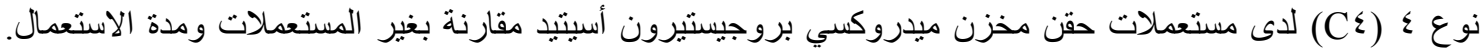

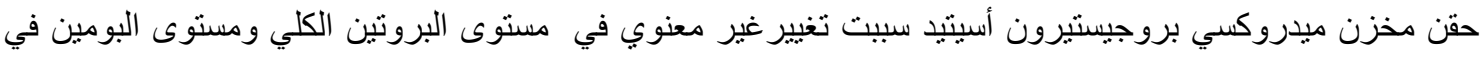

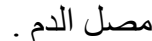

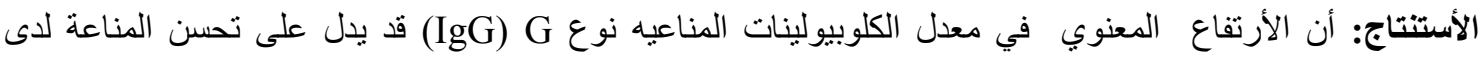

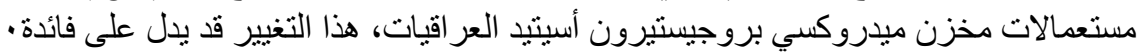

$\mathrm{D}$ epot medroxyprogesterone acetate is a long acting progesterone provided as paranteral contraceptive. It provides a very high level of contraceptive efficacy and it is effective as combined oral contraceptive pills (COCPs). In addition, DMPA injections may be particularly good choice for women in whom COCPs are either contraindicated or may cause additional health concerns.' It is usually given within the first 0 days of the menstrual cycle, by intramuscular injection as long acting preparations in a dose of $10 . \mathrm{mg}$ to provide contraception for up to $r$ months period.

Episodes of irregular, unpredictable spotting and/or break through bleeding within the first year of using DMPA injections, are most frequently encountered side effects. Long term use of DMPA injections may cause a reduction of menstrual blood loss, decrease risk of endometrial cancer and suppress the endogenous estrogen secretion; which lead to: reversible reduction in the bone density and changes in plasma lipids which are associated with increased risk of atherosclerosis ${ }^{r}$. Since atherosclerosis may in part, be an inflammatory disease, " thus circulating factors that are related to inflammation may be predictors of cardiovascular diseases in general population. ${ }^{\circ}$

The complement system and immunoglobulins are the main components of humeral immunity. The activation of complement is known to be involved in a number of forms of cardiovascular disease, such as exacerbation of myocardial defect following ischemic injury by complement activation "and may involved in the generation of spontaneous atherosclerotic lesions. ${ }^{\gamma}$ The third complement component ( $\left.\mathrm{C}^{r}\right)$, is a cytokine acute phase protein, and is produced by activated macrophages ", liver and adipose tissue $^{q}$. $\mathrm{Cr}$ and its fragments are recognized regulators of the humeral immune response and B- cell proliferation.'

Previous studies have clearly shown that both susceptibility and immune responses in the female genital tract are regulated by sex 
hormones", ir. In a rat model, it was previously shown that the stage of the estrous cycle and treatment with sex hormones, specifically estradiol and progesterone, influence both the inductive and effecter arm of the immune system in the genital tract" ${ }^{\prime \prime}$. Antigen presentation, immunoglobulin $A(\lg A)$ and $\lg G$ levels, IgA transport, and presence of immune cells are all under hormonal regulation ${ }^{1 \leqslant, 10}$. More recently these studies have been extended to cover the reproductive tract of women, demonstrating that similar regulation of immune responses exists in women during the menstrual cycle.'

It was found that the in vivo administration of medroxyprogesterone acetate (MPA) to mice, $v$. or $q$. days before immunization with sheep red blood, significantly enhanced antibody responses, without affecting delayed hypersensitivity. Also it was found that low doses of MPA significantly enhanced the in vitro production of IgG antibodies, and because MPA did not increase the number of immunoglobulinsecreting cells, it was suggested that MPA enhanced the capacity of individual cells to produce specific immunoglobulin."

The aim of this study was to evaluate the effects of DMPA usage for one year on serum immunoglobulins (IgG, IgM, IgA), and complements $\left(C^{r}, C \varepsilon\right)$, and total serum protein an serum Albumin.

\section{Subjects, Materials \& Methods}

This study included $r$. apparently healthy women who were attending Al-Batool Family Planning Centers in Mosul/ Iraq. The following inclusion criteria were put: The age ranges between r.-ro years old. Body Mass Index (BMI) for each women should be $<$ ro $(B M I=$ weight $(\mathrm{kg}) /$ height $\left.\left(\mathrm{m}^{r}\right)\right)$.' $^{\prime \prime}$ Each women should be: Married, not pregnant, not lactating but were fertile at the time of study, having regular menstrual cycle, apparently healthy with hemoglobin, not less than $1 . .0 \mathrm{gm} / \mathrm{dl}$, not be a hormonal contraceptives users before, or using any medications during the period of the study, neither having history of allergy nor any disease that interfere with the immune system such as systemic lupus erthymatosus, tuberculosis, rheumatoid arthritis and neither smoker nor alcoholic. They were just started to receive (for the first time) DMPA injection called "Depo-Provera" of Pharmacia NVISA PuursBelgium. Each injection contains 10. mg medroxyprogesterone acetate. These women called DMPA users group. The non users group included another $r \cdot$ apparently healthy women who have the same inclusion criteria as the DMPA users group except that they were not using any hormonal contraceptives, instead, they used either a barrier method or mechanical methods and they were volunteered for comparison. The two groups were followed by taking a detailed information which includes age in years, blood pressure $(\mathrm{mmHg})$, body weight $(\mathrm{Kg})$, height $(\mathrm{cm})$, number of children, parity, gravity, menstrual cycle, disease state (history or family history of hypertension, diabetes mellitus), if using other drugs, about smoking or consumption of alcohol and type of contraceptives used before. About 1. $\mathrm{ml}$ of venous blood were withdrawn, using a disposable syringe at about $\left.\Lambda_{.} 0_{-}\right) \cdot$ am from the DMPA injections users group at the beginning before they start taking the injection, after 7 months, then after ir months of use, and from the non contraceptive users group using the same schedule. The blood allowed to clot in a plain tube at room temperature and then the serum was separated by centrifugation at $r . .$. rpm for 1. minutes and then kept frozen at $r \cdot{ }^{\circ} \mathrm{C}$ to be analyzed for measuring serum level of:

1- Serum immunoglobulins (IgG, IgM, IgA) and serum complements $\left(C^{r}\right.$ and $\left.C \xi\right)$ which were measured by single radial immunodiffusion (RID) method using Kallestad Endoplate Single Radial Immunodiffusion Test Kit (Sanofi Diagnostics, France). The method of RID to quantitate $\mathrm{lg}$ depends on the relationship between antigen concentration and the diameter of the precipitin ring formed when the antigen diffuses from a cylindrical well into an antibody containing gel. The endpoint is reached when all of the antigen has reacted with antibody. ${ }^{19}$

r- Total Serum Protein: was measured by Biuret Method, ${ }^{r \cdot}$ using a Syrbio kit of total protein (Paris-France).

r- Serum Albumin: was measured by Bromocresol Green Method. ${ }^{r}$ using Syrbio kit of albumin (Paris-France). 
Standard statistical methods were used to determine the mean, standard deviation (SD) and the range. Paired t-test was used to compare the results of various biochemical parameters among DMPA users and nonusers. Linear regression analysis (Pearson correlation coefficient $\AA$ ) " " was performed for finding the degree of association between different parameters. ANOVA Test (analysis of variance) was used to identify the variation in the different variables in relation to the duration of DMPA users group. While Duncan's test was used to identify groups responsible for statistical difference through comparison. All values quoted as the mean \pm SD and a P-value of $<\cdot . \cdot 0$ was considered to be statistically significant. ${ }^{\text {"I }}$

\section{Results}

The (mean \pm SD) age of the DMPA users was $Y \wedge . r 4 \pm \leqslant$. . \& years, while the (mean \pm SD) age of the non users was $r v . \varepsilon+ \pm\{. V$ years. There was no significant difference between mean \pm SD height of the DMPA users (10v. ov \pm r.rr $\mathrm{cm}$.), and the mean \pm SD height of the non users $(109 . r \cdot \pm r . r 0 \mathrm{~cm}$.$) .$

Table 1 demonstrates that there was a significant increased in the serum IgG after ir months in the DMPA users in comparison with the non users. There was no significant difference in the mean serum IgG of the DMPA users and non users at the baseline time (. month).

ANOVA analysis among the DMPA users group indicated a non significant increase in the mean serum IgG according to the duration of DMPA injections use (Table ').

Table 1: Comparison between mean serum IgG level of DMPA user

\begin{tabular}{|c|c|c|}
\hline \multirow{2}{*}{$\begin{array}{l}\text { Period of use } \\
\text { (Months) }\end{array}$} & \multicolumn{2}{|c|}{$($ Mean \pm SD) Serum IgG $(\mathrm{mg} / \mathrm{dl})$} \\
\hline & $\begin{array}{c}\text { DMPA Users } \\
(\mathbf{n}=r \cdot)\end{array}$ & $\begin{array}{c}\text { Non Us } \\
(\mathbf{n}=r\end{array}$ \\
\hline - Month & 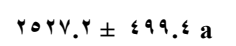 & rr.oz \\
\hline Months & 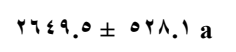 & rorv $=$ \\
\hline ir Months & 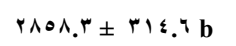 & rort \\
\hline
\end{tabular}

mean $\mathrm{Cr}$ of the DMPA users at the baseline time.

There were a non significant decrease in the total serum protein levels among DMPA users in comparison with the non users after 7 months but a significant decrease after ir months was noted while a non significant changes in the mean serum albumin among DMPA users in comparison to the non users after $r$ and ir months, and a non significant difference in the mean total serum protein and the mean serum albumin of the DMPA users and the non users at the baseline time.

ANOVA analysis of the DMPA users group also indicated a non significant variation in the mean serum $\operatorname{lgM}, \lg A, C^{r}, C \leqslant$, total serum protein, mean serum albumin of the DMPA users in relation to the duration of usage.

\section{Discussion}

The difference between male and female immune response are well documented. It has been determined that female sex hormones, especially estrogen and progesterone, have a 
distinct effect on immune function ${ }^{r r}$. The exact mechanism for this difference between men and women, however, is not clearly understood. Apparently both humeral and cellular immune activities are more aggressive in women than in men ${ }^{r r}$.

The present study illustrates that there is a significant increase in the mean serum $\lg G$ level after $1 r$ months of DMPA usage but a non significant variation in relation to the duration of use, while, non significance difference in IgM or IgA levels were observed. Although there was a significant decreas in total serum protein after ir months of DMPA injections usage in comparison to non users, but no significance difference in the mean serum albumin level and a non significant variation in relation to the duration of use of both. This study is in agreement with the study done by Lali, et al., ${ }^{\text {rs }}$ to determine the effect of DMPA as contraceptive on the levels of serum immunoglobulins, total protein and albumin in Indian users and found that levels of total protein and albumin remained unchanged. No significant changes were observed in the levels of IgA and IgM, while IgG levels were increased in the first and third month after DMPA injection, and the increase in the first month was statistically significant $(P=\cdot .19)$. This were indicative of improved humeral immunity in Indian DMPA users.

While the study done by Fajumi ${ }^{\text {ro }}$ found that treatment with DMPA injection produced increased serum levels of albumin, alpha '-acid glycoprotein, alpha r-macroglobulin, haptoglobulin IgG, reduced levels of alpha 1antitrypsin, trasferrin, $C{ }^{r} \mathrm{c}, \mathrm{C} \leqslant$ but no change in serum IgA, IgM, C-reactive protein and ceruloplasmin. The significant alterations were observed in serum proteins that are notably synthesized by the liver, an observation consistent with influences which gonadal hormones exert on the metabolic activities of this organ.

The effects of Uniplant R (a new, long-acting, 19-nor-progesterone derivative contraceptive) on serum immunoglobulins, albumin and total proteins were determined in Nigerian women

\section{References}

1- Laurance DR, Bennett PN, Brown MJ. Hypothalamic pituitary and sex hormones. In: during one year of use. Their results indicate that while Uniplant does not seem to alter the levels of $\lg A, \lg M$, albumin and total proteins over a period of twelve months, it may induce significant increase in IgG levels. The raised mean serum levels of lgG may suggest an improved humeral immunity of Uniplant-a change that is potentially beneficial ${ }^{r,}, r$.

Limited data were available from the literatures concerning the effect of DMPA on serum complement level, The data obtained from this study demonstrated that DMPA usage for one year caused a non significant changes in serum $\mathrm{Cr}^{r}$ and $\mathrm{C}$ ₹ level in the DMPA users in comparison with the non users after $r$ and $i r$ months, and a non significant variation in relation to the duration of use. This study is in contrast with the work of Yilmazer et al., ${ }^{r \lambda}$, who found that $\mathrm{Cr}^{r}$ level is significantly increase in healthy post menopausal women using oral ethinyl estradiol $(E E)$ + medroxyprogesterone acetate (MPA) than in similar women using transdermal $\backslash \vee \beta$ estradiol + MPA and those not on hormonal replacement therapy (HRT). In addition, serum $C \leqslant$ level also increase in women receiving $E E+M P A$ than untreated women.

The association of $\mathrm{lg}$ with cardiovascular diseases remains the subject of debate. It has been proposed that serum $\lg A, \lg G$ and $\lg E$ may be associated with cardiovascular diseases in dyslipidemic men ${ }^{r q}$ but others ${ }^{r, r r}$ have suggested that the increase in $\lg M$ and IgG level might be a consequence of the primary involvement of $\mathrm{Cr}$ as there was no independent association of $\operatorname{lgM}$ and $\lg \mathrm{G}$ with atherosclerosis and myocardial infarction. In contrast to this, in the present study there is significant negative correlation between $\mathrm{C} r$ and IgM level $(r=-\cdot v r v, p=\cdot .10)$ and a lesser non significant negative correlation of $C r$ with IgG, IgA level $(r=-. .09 \wedge, p=. .71 ; r=$ $\because 7, p=\cdot . \cdot \mathrm{rV})$ respectively.

This study concluded that the use of DMPA injections as contraceptives by Iraqi women cause a significant raise of serum levels of $\mathrm{IgG}$, a change that is potentially beneficial as may be indicative of improved humeral immunity. 
Clinical Pharmacology, $9^{\text {th }}$ ed. Laurance DR, Bennett PN, Brown MJ editors. Churchill Livingstone, London r...r. PP V.9_vrr.

Y- Parfitt K. Sex hormones. In: Martindale. The complete drug reference, $r r^{\text {nd }}$ edition. Parfitt $\mathrm{K}$, the editor. Pharmaceutical Press, USA

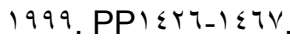

r- Chrousos GP, Zoumakis E, Gravanis A. The gonadal hormones and inhibitors. In: Basic and Clinical Pharmacology. $\lambda^{\text {th }}$ ed. Katzung BG, the editor. Mc Graw-Hill, USA $Y .$. . PPIVq-VI.

\&- Ross R. Atherosclerosis-an inflammatory

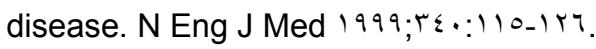

- Danesh J, Wheeler JG, Hirschfield GM et al., C-reactive protein and other circulating markers of inflammation in the prediction of coronary heart disease. The New Eng J Med

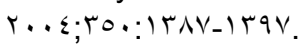

7. Gardinali M, Conciato L, Cafaro C, Agostino A. Complement system in coronary heart disease: a review. Immunopharmacol $1990 ; \mathrm{r} \cdot: 1 \cdot 0-11 \mathrm{~V}$.

V- Seifert PS, Kazatchkine MD. The complement system in atherosclerosis. Atheroscl $19 \wedge \lambda ; V r: q 1-1 . \varepsilon$.

^- Zimmer B, Hartung HP, Scharfenberger G, Bitter-Suermann P, Hadding U. Quantitative studies of the secretion of complement $\mathrm{Cr}^{r}$ by resident, elicited and activated macrophages. Comparison with $\mathrm{Cr}, \mathrm{C} \varepsilon$ and lysosomal enzyme release. Eur J Immunol 19Ar;1r: \&rr_\&r.

9. Choy LN, Rosen BS, Spiegelman BM. A dipsin and an endogenous pathway of complement from adipose cells, J Biol Chem

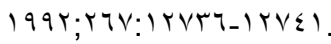

1.- Lenhardt W, Melchers F. The role of $\mathrm{Cr}^{\mathrm{r}}$ and its fragments in the control of $S$ phase entry of activated mouse B lymphocytes via the complement receptor type r. Exp Clin Immunogenet 1911;90:110-1Yr.

11- Gallichan WS, Rosenthal KL. Effects of the estrous cycle on local humeral immune responses and protection of intranasally immunized female mice against herpes simplex virus type $r$ infection in the genital tract. Virolo 1997; rY $\left\{:\left\{\wedge V_{-} \leqslant 9 V\right.\right.$.

Ir- Kaushic C, Zhou F, Murdin AD, Wira CR. Effect of estradiol and progesterone on susceptibility and immune responses to
Cblamydia tracbomatis infection in the female reproductive tract. Infec. Immunol

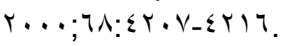

IT- Wira CR, Kaushic C, Richardson J. Role of sex hormones and cytokines in regulating mucosal immune system in the female reproductive tract, In by. Ogra PL, Lamm ME, Bienenstock J, Mestecky J, Strober W, and McGhee JR (ed.), Mucosal immunology. Academic Press, New York, N.Y 1999. PPI $\leqslant$ ११- I $\leqslant 7$.

I\{-Kaushic C, Richardson JM, Wira CR. Regulation of polymeric immunoglobulin $A$ receptor messenger ribonucleic acid expression in rodent uteri: effect of sex

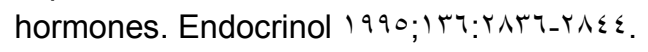

10-Wira CR, Sandoe CP. Sex steroid hormone regulation of immunoglobulin $G(\lg G)$ and $A$ $(\lg A)$ in rat uterine secretions. Nature

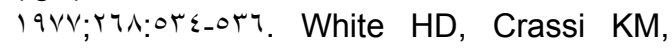
Givan $A L$ et al., $C D r+C D \wedge+C T L$ activity within the human female reproductive tract: influence of stage and menstrual cycle and menopause. J Immunol 199v; / ON; r. IV-r.rv.

17- White HD, Crassi KM, Givan AL et al., CDr+ $C D \wedge+C T L$ activity within the human female reproductive tract: influence of stage and menstrual cycle and menopause. J Immunol 199V;10N;r. IV-r.r.

i $V$-Vermeulen $M$, Pazos $\mathrm{P}$, Lanari $\mathrm{C}$ et al., Medroxyprogesterone acetate enhances in vivo and in vitro ! antibody production.

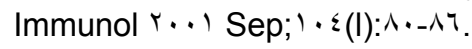

1A-Leemarkers EA, Dunn AL, Blair SN. Exercise management of obesity. Medical Clinic of North American $r \cdots ; \wedge \varepsilon(r): \leqslant 19-\varepsilon r_{0}$

19-Mancini G, Carbonara AO, Heremans JF. Immunochemical quantitation of antigens by single radial immunodiffusion. Immunochem 1970;r: YrO-YO\&.

r.-Johnson AM, Rohlfs EM, Silverman LM. Proteins. In: Tietz Textbook of Clinical Chemistry. ${ }^{\text {rd }}$ ed., Buritis CA, Ashwood ER editors. W.B. Saunders Company, USA 1999. PP $₹ Y V_{-} 0 \leqslant$.

$r$-Kirkwood BR. Essential of Medical statistics $1^{\text {st }}$ ed. Blackwell Scientific publications, Oxford 1914. PPะr-07.

Yr-Erbach GT, Bahr JM. Enhancement of in vivo humeral immunity by estrogen: permissive 
effect of a thymic factor, Endocrinol

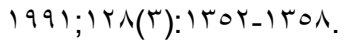

$r$-Racheve $\mathrm{C}$ et al., Sex differences information of anti-T-cell antibodies. Nature $19 \vee \div ; r \tau r: \varepsilon 10_{-}$ 纟1^.

r \&-Lali P, Chandra L, Gupta RP. Serum immunoglobulin levels during contraceptive use of depot-medroxyprogesterone acetate in Indian women: a preliminary study. Contracept 1997;0r(7):rтr-rтo.

ro-Fajumi JO. The effects of Depo-Provera on serum protein levels in Nigerian women. $J$

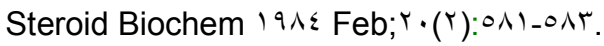

rı-Ajdekunie AQ, QkunloJla MA, Arowojoju AO, Arinoia ', Salim.onu LS. Serum. immunoglobulins, total protein and albumin levels during Uniplant $R$ use by Nigerian

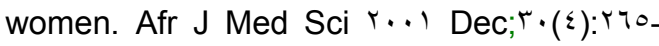
rฯA.

rV-Otolorin EQ, Adeyefa I, Konje JC, Ojengbede Q, Osotimehin B, Ladipo QA. Plasma immunoglobulin, total protein and albumin levels during Norplant use by Nigerian women. Acta Obstet Gynecol Scand 1994 Nov; $\forall r(\wedge): \tau \leq 0-\tau \leq v$.

r^-Yilmazer M, Fenkci V, Fenkci S, Aktepe O, Sonmezer M, Kurtay G. Association of serum complement $(\mathrm{Cr}, \mathrm{C} \xi)$ and immunoglobulin (IgG, IgM) levels with hormone replacement therapy in healthy postmenopausal women. Human Reproduct r...r; 1

rq-Kovanen PT, Manttari AA, Palosuo T, Manninen V, Aho K. Prediction of myocardial infraction in dislipidemic men by elevated levels of immunoglobulin classes A, E and $G$,

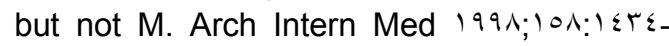
$1 \leqslant r q$.

r.-Muscari A, Bozzoli C, Puddu GM et al.,. Association of serum $\mathrm{Cr}$ levels with the risk of myocardial infraction. Am $\mathrm{J}$ Med 1990;91:rov-rus.

r)-Muscari A, Puddu P. Immunoglobulins, $\mathrm{Cr}$ and the risk of myocardial infarction. Arch Inter Med 1999;109:rrus-rrq. 